\title{
Third contribution to the knowledge of Sicilian spider fauna (Arachnida Araneae)
}

\author{
Antonino Dentici \\ via Enrico Cialdini 2, 90124 Palermo, Italy; e.mail: a.dentici@virgilio.it
}

\begin{abstract}
The following work shows new or interesting data on the araneofauna of Sicily (Arachnida Araneae). Particularly, 2 genera and 7 species new for Sicily are reported and the presence of Linyphia triangularis (Clerck, 1757) is confirmed. Additional biological, ecological and faunistic data are provided.
\end{abstract}

KEY WORDS Araneae; Sicily; new data.

Received 26.03.2019; accepted 10.05.2019; published online 05.06.2019.

\section{INTRODUCTION}

The arachnological researches carried out in Sicily in the last years to improve the knowledge on the araneofauna (Dentici 2017; Dentici \& Amata 2018) allowed me to find new or at least interesting data that are reported in this work.

Particularly, 2 genera and 7 species new for Sicily are reported. The presence of Linyphia triangularis (Clerck, 1757) is confirmed for this island after the first observation by Pavesi (1868), little known in bibliography (see Pantini \& Isaia, 2018).

\section{MATERIAL AND METHODS}

All samples were collected on sight under rocks or barks or in their web.

All the samples, brought to laboratory, were treated with ethyl acetate, observed with binoculars and photographed with a Nikon d90 reflex and a macro lens of $100 \mathrm{~mm}$ with a series of extension tubes for identification. The program Helicon focus 6 was used to merge images taken at different focal planes into single images with greater depth of field.

The specimens were stored in centrifuge tubes of different sizes, depending on the size of the sample, and were fixed in $75 \%$ ethanol and are stored in the collection of the author.

For each species literature, chorotype and distribution, biological notes and collector are indicated. The locality and/or collection site are cited in the original language (Italian).

The classification, taxonomic order, nomenclatural arrangement, and presence in the Sicilian territory follow Roberts (1995), Trotta (2004), Pantini \& Isaia (2018), and World Spider Catalog (2019). Other sources have also been used for the correct identification and are, when used, signed in the species remarks.

\section{RESULTS}

\section{Systematics}

Ordo ARANEAE Clerck, 1757

Familia AGELENIDAE C.L. Koch, 1837 
Genus Tegenaria Latreille, 1804

Tegenaria hasperi Chyzer, 1897 Figs. 1, 2

EXAmined MATERIAL. Italy, Sicily, Palermo, Godrano, Bosco della Ficuzza, 37051'18”N, $13^{\circ} 25^{\prime} 23^{\prime}$ "E, 05.VIII.2017, 1 female, legit R. Viviano.

Distribution. France to Turkey, Russia (Europe).

REMARKS. The specimen was collected in the mouth of his retreat, his canvas was built in a crack in the rock and there were several other canvases like this nearby. New species for Sicily.

Familia ARANEIDAE Clerck, 1757

Genus Leviellus Wunderlich, 2004

Leviellus kochi (Thorell, 1870) Fig. 3

Examined material. Italy, Sicily, Palermo, Prizzi, 37²4'13.2”'N 132 23'43.6”'E, 30.VI.2018, 1 male, legit A. Dentici.

Distribution. Southern Europe, North Africa, Central Asia.

REMARKs. The specimen was sampled during the night (1:30 am approximately), wandering on the bark of a tree, perhaps in search of a female. New genus and new species for Sicily.

Familia FILISTATIDAE Ausserer, 1867

Genus Pritha Lehtinen, 1967

Pritha pallida (Kulcynski, 1897) Fig. 4

Examined Material. Italy, Sicily, Agrigento, San Biagio Platani, 37³2’34”N 13'32’39”E, 21.VII.2018, 1 female and 1 female subadult, legit R. Viviano.

Distribution. Mediterranean.

REMARKS. The specimens were collected under rocks during daylight hours. The identification of the specimens follow Legittimo et al. (2017). New genus and new species for Sicily.
Familia GNAPHOSIDAE Pocok, 1898

Genus Gnaphosa Latreille, 1804

Gnaphosa dolosa Herman, 1897 Fig. 5

EXAMINED MATERIAL. Italy, Sicily, Palermo, Misilmeri, 3759'33.4”N 13²7'51.4'E, 15.XII.2014, 1 male, legit A. Dentici.

Distribution. Southern to Eastern Europe, Turkey, Syria, Iran, Caucasus, Russia (Europe) to Central Asia

REMARKS. Specimen collected under a wooden slab, wintering inside its silk cell. New species for Sicily.

Familia LINYPHIIDAE Blackwall, 1859

Genus Linyphia Latreille, 1804

Linyphia triangularis (Clerck, 1757) Fig. 6

Examined material. Italy, Sicily, Palermo, Monreale, Caculla, $38^{\circ} 02^{\prime} 59^{\prime \prime} \mathrm{N}, 13^{\circ} 14^{\prime} 40^{\prime \prime} \mathrm{E}$, 05.IX.2018, 1 male, legit Antonino Dentici; Sicily, Palermo, Monreale, Caculla, $38^{\circ} 02^{\prime} 59.1^{\prime \prime} \mathrm{N}$, 1314'35"E, 09.IV.2019, 1 male, legit A. Dentici.

Distribution. Europe, Caucasus to Iran, Russia to China. Introduced to USA.

REMARKS. Specimen collected in its web. The discovery of this species, already observed by Pavesi (1878), confirms its presence (see Pantini \& Isaia, 2018).

Familia TETRAGNATHIDAE Menge, 1866 Genus Metellina Chamberlin et Ivie, 1941

Metellina mengei (Blackwall, 1869)

EXAmined MATERial. Italy, Sicily, Palermo, Giacalone, Casaboli, $38^{\circ} 04^{\prime} 12.8^{\prime \prime} \mathrm{N}, 13^{\circ} 13^{\prime} 35.2^{\prime \prime} \mathrm{E}$, 07.IV.2019, 1 male and 1 female, legit A. Dentici.

Distribution. Europe to Caucasus, Iran, Russia (Europe to Altai).

REMARKS. Both specimens were collected in the same web. New species for Sicily. 


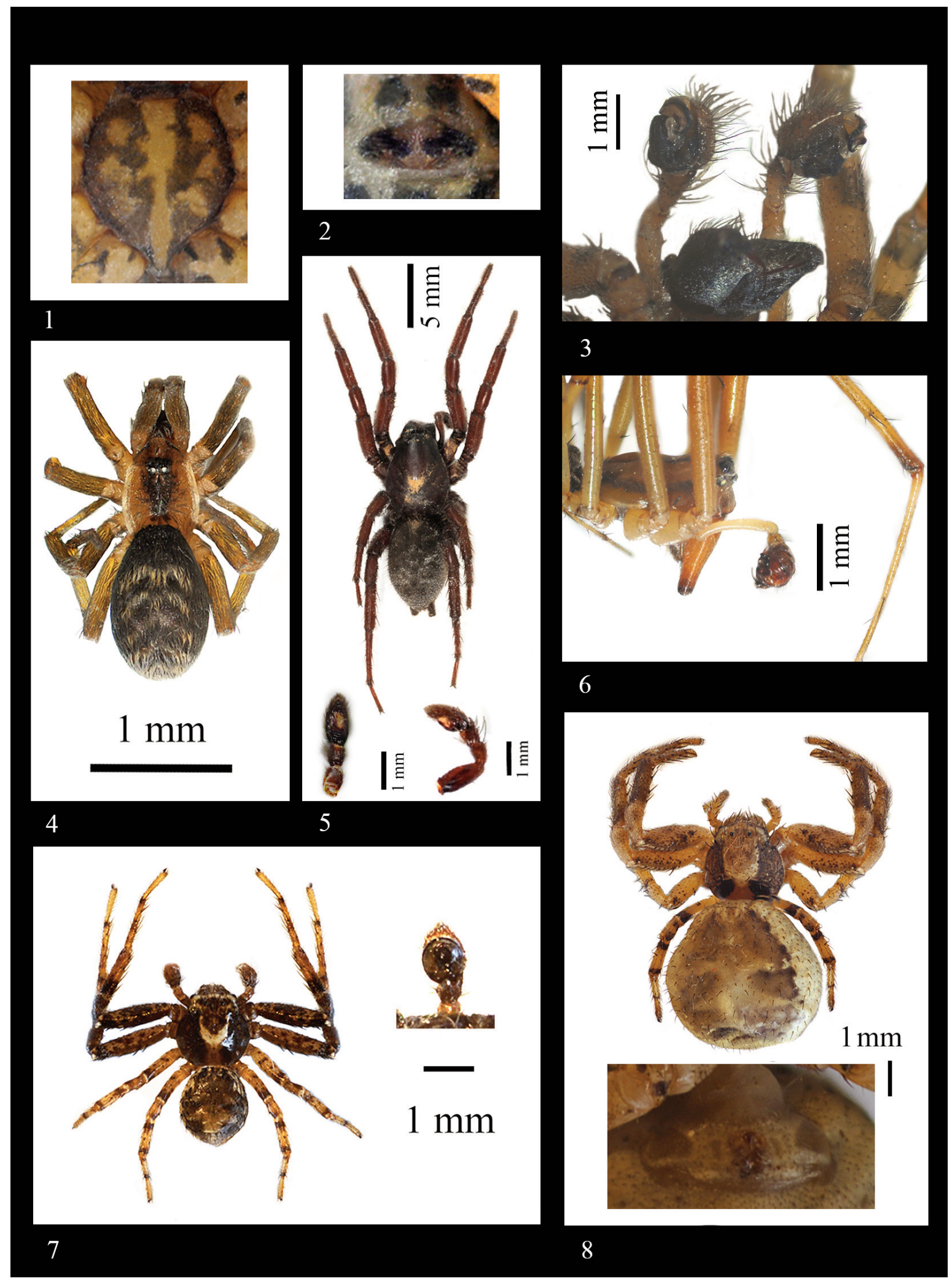

Figures 1, 2. Tegenaria hasperi: sternum (Fig. 1) and epygine (Fig. 2). Figure 3. Palpi of Leviellus kochi. Figure 4. Pritha pallida, habitus. Figure 5. Gnaphosa dolosa: habitus and palpi. Figure 6. Palpus of Linyphia triangularis. Figure 7. Xysticus desidiosus male: habitus and palpus. Figure 8. Idem, female. 
Familia THOMISIDAE Sundevall, 1833

Genus Xysticus C.L. Koch, 1835

Xysticus desidiosus Simon, 1875 Figs. 7, 8

Examined material. Italy, Sicily, Palermo, Bagheria, 09.IV.2017, 1 female, legit R. Viviano; Sicily, Palermo, Monreale, Bosco di Ficuzza, $37^{\circ} 52^{\prime} 48.8^{\prime \prime} \mathrm{N}, 13^{\circ} 22^{\prime} 43.7^{\prime \prime} \mathrm{E}, 1$ male, legit A. Dentici.

DisTRIBUTION. Europe.

REMARKS. Both specimens were found on the ground beneath rocks. New species for Sicily.

Genus Xysticus C.L. Koch, 1835

Xysticus nubilus Simon, 1875

Examined material. Italy, Sicily, Palermo, Monreale, Caculla, 3803'03.7' N, 13'14'45.1'E, 22.IV.2018, 1 male, legit A. Dentici.

Distribution. Macaronesia, Mediterranean, Georgia.

REMARKS. This species was collected under bark of Eucalyptus. New species for Sicily.

\section{ACKNOLEDGMENTS}

I would like to thank Ignazio Sparacio (Palermo, Italy) and Paolo Pantini (Bergamo, Italy) for their help, Marco Capritti (Palermo, Italy) and Roberto Viviano (Palermo, Italy) for their true friendship, and my girlfriend Valeria Lo Bianco (Palermo, Italy) and all my family for their essential support.

\section{REFERENCES}

Dentici A., 2017. Contribution to the knowledge of Sicilian spider fauna (Arachnida Araneae). Biodiversity Journal, 8: 861-864.

Dentici A. \& Amata F.C., 2018. New faunistic data for the Sicilian Aracnofauna (Arachnida Araneae). Biodiversity Journal, 9: 271-276. https://doi.org/10. 31396/Biodiv.Jour.2018.9.3.271.276

Legittimo C.M., Simeon E., Di Pompeo P. \& Kulczycki A., 2017. The Italian species of Pritha (Araneae, Filistatidae): a critical revision and description of two new species. Zootaxa, 4243: 201-248. https://doi. org/10.11646/zootaxa.4243.2.1

Nentwig W., Blick T., Gloor D., Hänggi A. \& Kropf C., 2019. Version \{no. of month\}2019. Online at https://www.araneae.nmbe.ch, accessed on 31.III.2019. https://doi.org/10.24436/1

Pantini P. \& Isaia M., 2018. Checklist of the Italian spiders (Version June 2018).

Pavesi P., 1878. Nuovi risultati aracnologici delle Crociere del "Violante". Aggiunto un catalogo sistematico degli aracnidi di Grecia. Annali del Museo civico di Storia naturale di Genova, 11: 337-396 .

Roberts M.J., 1995. Spiders of britain and Northern Europe. Harper Collins, London, 383 pp.

Trotta A., 2004. Introduzione ai Ragni italiani (Arachnida Araneae). Memorie della Società Entomologica Italiana, 83: 3-178. https://doi.org/10.4081/memorieSEI. 2004.3

World Spider Catalog, 2019. World Spider Catalog, version 20.0. Natural History Museum Bern, online at http://wsc.nmbe.ch (20.01.2019) https://doi.org/10. $24436 / 2$ 